point of the funnel into the latter, and emptying the contents of the larger bottle into the funnel.

When he comes to use the brush, the collector soon sees that his manipulation must be varied according to the habit of the different species. The active high-strung Isotoma and the nervous Tomocerus must be "flipped" or herded into the bottle with a dry brush, while the non-leaping kinds, such as Neanura and Onychiurus and stolid genera like Achorutes and Xenylla can be picked up on a moistened brush without any trouble. Whatever others may say, the enthusiast sees no objection to moistening the brush with the lips. The absorption of an odd Collembolan that this practice may sometimes entail is entirely negative in result, as I can testify from several years' experience.

The insects are brought home alive, and are best killed, as Dr. Folsom advises, by theapplication of 95 percent. alcohol heated almost to a boiling point. They may be then transferred to 80 per cent. alcohol for preservation. Springtails should never be mounted on points, as they soon shrivel up. Microscope preparations in Canada balsam, Dr. Folsom says, tend to shrink, and he suggests a mixture of glycerine jelly and acetic acid as the most satisfactory medium. An invaluable tool for "setting up" springtails and all other minute insects was discovered by Mr. J. M. Swaine, of the Entomological Branch, Ottawa, in the fine-pointed flexible wire instrument used by dentists to extract nerves, and known technically as a "broach."

As doubtless many collectors have discovered for themselves, the best work is done when one is alone. Unless your companion is equally interested with you in the particular insect you are after, his impatience and desire to move on distract, and his lack of sympathy chills you. I know people who could not watch one hour while a $\log$ was being examined with a magnifying glass, and whom even the discovery of a rare Pseudachorutes left quite cold.

\title{
THE BEES OF GOLD HILL, COLORADO.
}

BY T. D. A. COCKERELL, BOULDER, COLORADO.

Gold Hill is a small mining town in the mountains of Boulder County, Colorado, with an altitude of about 8,600 feet. It is rather well known in zoological circles because it was the residence of an indefatigable student of birds and mammals, Denis Gale. At Ward, a few miles away, Gale discovered the mouse which Merriam named Evotomys galei. On July 13, 1919, my wife and I spent the forenoon collecting bees at Gold Hill, on the dry hill immediately east of the town. Twenty species were obtained, listed below. The fauna is by no means entirely of the boreal type; one species, Andrena prunorum, extends to Southern New Mexico.

Prosopis varifrons Cresson. Females at Rubus.

Colletes kincaidii Ckll. Both sexes abundant at flowers of Frasera (Tessaranthium).

Sphecodes eustictus Ckll. Female at Geranium.

Halictus cooleyi Crawford. Common, visiting Frasera.

Halictus lerouxii Lepeletier. One male.

Halictus nigricollis Vachal. One male. Described by Vachal from a male December, 1919 
in the Vienna Museum, collected by Morrison in Colorado, and not previously recognized by me.

Halictus arapahonum Ckll. One male, this sex previously unknown. It is like $H$. provancheri nearcticus (Vach.), but the abdomen is olive green, with very distinct, faintly ochreous hair bands. Femora light ferruginous, without dark markings.

Halictus pruinosiformis Crawford. One female.

Halictus ruidosensis Ckll. One female; a rather large form with strongly dusky wings, perhaps separable.

Halictus galei, n. sp. ㅇ․ Length about $4.5 \mathrm{~mm}$; head and thorax bluish green, not bright, somewhat shining but not polished; hair of head and thorax white, not dense; head oblong, facial quadrangle much longer than broad; front minutely excessively densely punctured all over, but this does not extend to the region between the ocelli; antennæ black, flagellum obscurely reddish beneath toward end; tegulæ dark, not punctured; wings clear hyaline, nervures and stigma testaceous; mesothorax micrcscopically tessellate and with distinct punctures, about the diameter of a puncture apart; area of metathorax with very irregular strong plicæ, and smaller ridges between, the apical part hardly sculptured, its surface microscopically reticulate; legs black; hind spur with three long spines; abdomen black, shining; sides of second segment (especially basally) and all of the following covered with white hair, not so dense as to entirely hide the shining surface, the little hairs beautifully plumose; hind margins of second and following segments narrowly pallid.

In my manuscript key to the subgenus Chloralictus this runs to $H$. perdifficilis Ckll., which it resembles in the hairy abdomen. It differs from perdifficilis by being very much smaller, with narrower head, and also in coloration. The narrowerface, with straighter inner orbits, at once separates it from H. ruidosensis, but the peculiarity is not carried nearly so far as in $H$. longiceps Rob., which I have from Southcrn Pines, N. C. (Manee).

Andrena lupinorum Ckll. Common on flowers of Rubus, and also collected from Potentilla. I had only the type of this fine species.

Andrena apacheorum Ckll. One female at Potentilla.

Andrena prunorum Ckll. Female at Rubus; scape red, clypeus mainly red. Melissodes confusiformis Ckll. One male at Geranium.

Epeolus hitei Ckll. One male at Geranium; differs from the female by having the first two antennal joints black, and the third red only in part. I had only the unique type of female.

Anthophora smithii Cress. One male.

Chelynia elegans Cress. One male at Geranium.

Osmia armaticeps Cress. One female at Gaillardia.

Megachile pugnata Say. Both sexes at Gaillardia.

Bombus juxtus Cress. Workers common on Frasera.

The Rubus referred to is $R$. melanolasius Focke.

Summing up the principal results; the morning's collecting gave us one new species, two previously unknown males, one species described in Europe and not before recognized by us, and several specimens of a species of which we previously had only the single type. Also, the $M$. confusiformis was the first male in good condition. In connection with $\mathrm{Mr}$. Sladen's recent interesting 
observations on the relation between climate and characters, it may be of interest to note that in a considerable series of Chloralictus, the tegulæ are dark in those species which come from the north and the mountains, light in those from the south and lowlands. Thus:

Tegulæ dark. H. cressonii, nigroviridis, viridatus, perdifficilis, versans, ruidosensis, hortensis, planatus, etc.

Tegulæ light. H. semibrunneus, sparsus, floridanus, ashmeadii, versatus, zephyrus, gemmatus, bruneri, exiguus, etc.

\section{A LIST OF SYRPHIDÆ OF NORTHERN INDIANA.}

BY M. R. SMITH, RALEIGH, N.C.

The following is a list of Syrphids collected in the vicinity of Plymouth, Indiana, during the summer of 1918. As the writer does not think he will have opportunity to collect in this region again, this short list is being published with the hope that it may be of interest to the Syrphidologist and to those interested in working up the State's fauna.

To Mr. J. M. Craig much credit is due for assistance in collecting.

The writer also wishes to acknowledge his indebtedness to Mr. C. L. Fluke for a number of the determinations.

UPLAND SPECIES.

Eristalis tenax Linn.

E. arbustorum Linn.

E. transversus Wied.

E. dimidiatus Wied.

Sphaerophoria scripta Linn.

S. cylindrica Say.

Paragus bicolor Fabr.

P. tibialis Fabr.

$P$. angustifrons Loew.

Allograpta obliqua Say.

Mesogramma marginata Say.

$M$. geminata Say.

$M$. polita Say.

Syrphus ribesii Linn.

S. americanus Wied.

S. xanthostomus Williston.

S. abbreviatus Zett.

Syritta pipiens Linn.

Milesia virginiensis Drury.

Spilomyia hamifera Loew.

$S$. longicornis Loew.

Baccha fascipennis Wied.

Xanthogramma flavipes.
MARS̄H SPECIES.

Helophilus similis Macq.

$H$. latifrons Loew.

$H$. divisus Lcew.

$H$. chrysostomus Williston.

$H$. conostomus Williston.

$H$. laetus Loew.

Volucella evecta Walker.

$X$ ylota fraudulosa Loew.

$X$. ejuncida Say.

Tropidia quadrata Say.

T. calcarata Williston.

Pyrophaena rosarum Fabr.

$P$. granditarsus Fabr.

Platychirus quadratus Say.

$P$. hyperboreus Staeger.

Melanostoma mellinum Linn.

M. obscurum Say.

Neoascia globosa Walker.

Chrysotoxum pubescens Loew.

Pterallastes thoracicus Loew.

Eristalis bastardi Macq.

E. flavipes Walker. 


\section{$2 \mathrm{BHL}$ Biodiversity Heritage Library}

1919. "The bees of Gold hill, Colorado." The Canadian entomologist 51, 271-273. https://doi.org/10.4039/Ent51271-12.

View This Item Online: https://www.biodiversitylibrary.org/item/22089

DOI: https://doi.org/10.4039/Ent51271-12

Permalink: $\underline{\text { https://www.biodiversitylibrary.org/partpdf/4948 }}$

\section{Holding Institution}

MBLWHOI Library

\section{Sponsored by}

MBLWHOI Library

\section{Copyright \& Reuse}

Copyright Status: NOT_IN_COPYRIGHT

This document was created from content at the Biodiversity Heritage Library, the world's largest open access digital library for biodiversity literature and archives. Visit BHL at https://www.biodiversitylibrary.org. 